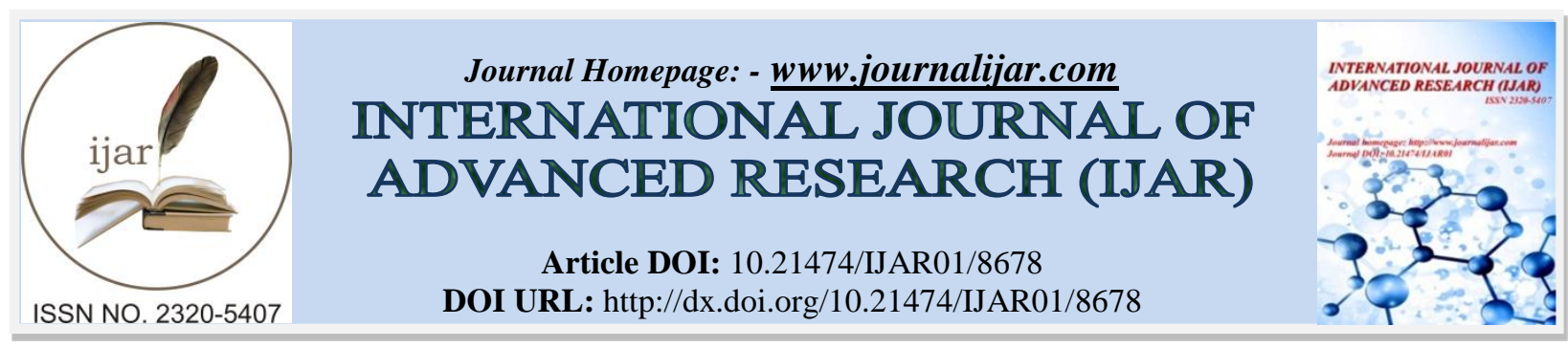

RESEARCH ARTICLE

\title{
MERGERS AND ACQUISITIONS: AN EMERGING ERA OF CORPORATE WORLD.
}

Palak Goel ${ }^{1}$ and Dr. Vijay Srivastava ${ }^{2}$.

1. BB.A. - LL.B. $(\mathrm{H}), 5^{\text {th }}$ year, Law College Dehradun, Uttaranchal University.

2. Assistant Professor, Law College Dehradun, Uttaranchal University.

\section{Manuscript Info}

Manuscript History

Received: 12 January 2019

Final Accepted: 14 February 2019

Published: March 2019

\section{Abstract}

Copy Right, IJAR, 2019,.All rights reserved.

\section{Introduction:-}

“Mergers are like marriages. They are bringing together of two individuals. If you wouldn't marry someone for the 'operational efficiencies' they offer in running of a household, then why would you combine two companies with unique cultures and identities for that reason?"

-Simon Sinek ${ }^{1}$

Looking to the magnitude of the company's business and commercial activities and diversities of interests of persons who deal with them, occasions of clash and conflict often arise which need to be resolved amicably. The companies, therefore, have to resort to arbitration or compromises to settle their disputes or differences by mutual consent of the parties. That apart, at the certain stage of its development it may become necessary for the company to reorganize itself by entering into compromises with its members and creditors or it may also have to join another company either by amalgamation or takeover.

The Companies Act, 2013 emerged as a new era to the corporate sector and replaced the 1956 Act with some sweeping changes including those in relation to the mergers and acquisitions. The new Act is eulogized by corporate entities for its business-friendly corporate regulations, enhanced disclosure norms and providing protection to investors and minorities, among other factors, thereby making the process of merger and amalgamation more amicable and smooth.

Merger and Acquisition is an emerging trend. Companies decide to engage themselves for merger and acquisition for the diversification of business, synergy of energy and resources, to get a competitive advantage, to improve efficiency and to enhance growth. The most important factor behind this concept is the SYNERGY - operational, financial and managerial.

\section{Meaning of Merger and Acquisition}

The term 'merger' and 'amalgamation' are used as synonyms to each other. The term 'amalgamation' has not been defined in The Companies Act, 2013. But in the context of Section: $\mathbf{2 3 2}^{\mathbf{2}}$, it implies amalgamation of one company with another in order to facilitate reconstruction of the amalgamating companies. In other words, 'amalgamation'

\footnotetext{
${ }^{1}$ Simon Sinek, Start With Why.

${ }^{2}$ The Companies Act, 2013
} 
takes place when two or more companies are joined to form a third entity or one is absorbed or blended with another ${ }^{3}$.

According to the English Oxford Dictionary ${ }^{4}$, 'merger' means a combination carrying a sense of coalescing or uniting two or more things together. In the corporate extent, it means uniting or combining two undertakings together.

According to the Transfer of Property Act, $1882^{5}$, a merger occurs when two estates held in the same legal right become united in the same person. A merger in respect of mortgage arises by commonly (i) by mortgages; and (ii) by the purchaser of the equity of redemption redeeming the mortgagee.

According to J.C. Verma ${ }^{6}$, the merger is a combination of two or more companies into a single company where one survives and the other loses its corporate existence.

In Re South African Supply Co. ${ }^{7}$, the Court interpreted amalgamation to connote "blending of two or more undertakings into one undertaking, the shareholders of each blending company becoming substantially the shareholders in the company which holds the blended undertakings."

Oxford Economic Papers defines acquisition as the process wherein the company 'B' acquires the whole of or a controlling interest in the share capital of company ' $\mathrm{A}$ ', the practical result is for many purposes the same as an amalgamation of the two companies, although legally the two companies and their undertakings still remain distinct $^{8}$.

Merger and Acquisition are often mistaken to be used interchangeably. But looking at the result of two concepts, both are poles apart to each other. Merger refers to the type of business combination whereby two different entities or organizations join together a form a new entity. In other words, a merger is a positive aspect of the consolidation strategy in which one company, i.e., the surviving company takes over another company, i.e., the merged company. Instead, the term acquisition means when one company is purchased by another company. In other words, an acquisition is a negative aspect of consolidation strategy in which no new entity is formed, unlike in merger, but the purchasing company remains and absorbs the acquired company.

\section{Types of Mergers and Acquisitions}

The different types of mergers and acquisitions based on the line of the business strategy are as follows:

1. Horizontal Merger/Acquisition

This kind of merger is also known as 'horizontal integration'. This kind of merger takes place between entities engaged in competing for business which are at the same stage of the industrial progress ${ }^{9}$. Such organisations are in direct competition in the same product lines and market. This kind of merger had dual advantages to the organisation in the form of economies of scale and economies of scope. Such kind of merger is scrutinized by the competition commission.

\section{Vertical Merger/Acquisition}

When two entities upholding different stages of the industrial or production level, nature of the merger of such entities is known as a vertical merger. Such type of merger moves a company to be more independent and selfsufficient. For instance, the merger of a company engaged in the production of bricks or steel with a company that is engaged in construction business. In other words, the vertical merger means the merger of the supplier and the company or the customer and the company.

\footnotetext{
${ }^{3}$ Somayujula v. Hope Prudhomme \& Co. Ltd., (1963) 2 Comp LJ 61.

${ }_{5}^{4}$ Oxford Dictionary, 2003, p.no. 564.

${ }^{5}$ Section: 101 of the Transfer of Property Act, 1882.

${ }^{6}$ J.C. Verma, Corporate Mergers Amalgamation and Takeovers, Bharat Law House, New Delhi, 2009.

${ }^{7}$ (1904) 2 Ch. 268.

${ }^{8}$ Mergers \& Acquisitions, Impact of Acquisitions on Company Performance, Oxford Economic Papers, Volume 49, July 1997.

${ }^{9}$ Corporate Mergers Amalgamations and Takeovers, J.C. Verma, $4^{\text {th }}$ edition, 2002, p.59.
} 


\section{Conglomerate Merger/Acquisition}

When two companies involved in two different market or having unrelated industries and products, the merger of such companies is known as conglomerate merger or acquisition. The main motive(s) behind such merger is the utilization of financial resources, enlargement of debt capacity, an increase in the value of outstanding shares by increased leverage and earnings per share, and by lowering the average cost of capital ${ }^{10}$. Such merger also led to foray the business without incurring the large set-up costs.

\section{Congeneric Merger}

A congeneric merger takes place when two entities or industries having the same market or business but offering different products. Such type of merger doesn't give rise to the buyer-seller relationship. This merger is also known as 'concentric merger'. It includes an extension of the product line or acquiring components that are required in the daily operations. This kind offers great opportunities as it opens a huge gateway to diversify around a common set of resources and strategic requirement.

\section{Historical Merger and Acquisition Waves}

Merger and Acquisition is not a new concept to the corporate world rather the subject dates back to 1800 s. With the increasing competitiveness in the global economy and business landscape, the two aspects became instrumentalities for its application resulting in expansion by the means of Merger and Acquisition. This led to the emergence of the phenomenon called 'merger wave'.

The evolution of the merger and acquisition can be broken down into seven phases or waves as follows:

1. First Wave (1893-1904)

This wave is generally known as 'great merger movement' leading to the emergence of the horizontal mergerswhere firms operate within the same industry or field as competitors- combine together. This is often opted by the large organisations for effective economies of scale as the companies coming together are engaged in the same industry of field. This is attracted by the companies who wanted monopoly or market dominance. Some of the horizontal mergers of this wave are Standard Oil Company of New Jersey in 1899, United States Steel Corporation in 1901, International Harvester Corporation in 1902 and many more.

2. Second Wave (1919-1929)

With the whopping rate of the horizontal merger during the First World War, it created monopolies resulting in the intervention of the mechanism of the government and enactments banning the concept of 'anticompetitive behaviour'. This led to the companies switching from the horizontal consolidation to vertical restructuring which emerged as a new facet of the Second World War.

The major player of this era was the merger of the Ford and FIAT making them leaders of the pack. Vertical mergers are more efficiency-oriented; rather than increasing revenue, the goal is to reduce the costs and improve the company's overall efficiency. This type of merger involves two companies that are not competitors but collaborators, in the sense that they used to purchase from each other in the past. Thus, it is a common sight to see a bidder and buyer expanding the company's operations towards the resources (upstream) or the end-user (downstream) $)^{11}$.

3. Third Wave (1955-1970)

The main drivers that rolled up this phase are diversification and expansion. Both of the above phase strategies, horizontal and vertical mergers, failed due to several loopholes, the companies adopted its restructuring through conglomerate mergers and acquisitions.

When two companies involved in two different market or having unrelated industries and products, the merger of such companies is known as a conglomerate merger. The main motive(s) behind such merger is the utilization of financial resources, enlargement of debt capacity, an increase in the value of outstanding shares by increased leverage and earnings per share, and by lowering the average cost of capital ${ }^{12}$. Such merger also led to foray the business without incurring the large set-up costs.

\footnotetext{
${ }^{10}$ Financial Management and Policy- Text and Cases, V.K. Bhalla, $5^{\text {th }}$ revised edition, p. 59.

${ }^{11}$ A Historical Analysis of M\&A Waves, by Anastasia.

${ }^{12}$ Ibid.
} 
One of the major mergers of this wave is of General Electric Company. However, it didn't last long.

4. $\quad$ Fourth Wave (1974-1989)

The Fourth Wave witnessed the arrival of the corporate raiders, hostile takeovers and congeneric mergers on the scene. 'Corporate Raiders' was given the name to the financer or investor who tends to take control of the company or business by the means of acquisition of the large shareholdings or the interests vested therein. 'Hostile Takeovers' refers to a kind of corporate restructuring in which merger or acquisition without the wishes or even the consent of the shareholders, owners, or even management of the company happens. This type of takeover is on the unfriendly side and requires lots of friction by everyone involved.

A congeneric merger takes place when two entities or industries having the same market or business but offering different products. Such type of merger doesn't give rise to the buyer-seller relationship. This merger is also known as 'concentric merger'. It includes an extension of the product line or acquiring components that are required in the daily operations. This kind offers great opportunities as it opens a huge gateway to diversify around a common set of resources and strategic requirement.

This wave came to an end in 1989 because of the banks' lending up too much and too often, that they were unable to maintain their capital structures resulting in the closing of doors of many companies.

5. Fifth Wave (1993-2000)

In the 90s, many businessmen urged for greater 'economies of scale'. This resulted in the creation of conglomerates and multinational companies at a greater scale dominating the market. This phase or wave welcomed the 'crossborder mergers'. It means when two companies having their registered offices in two different nations merge together to develop the dominance in the international as well as global scale.

It involves two companies with the land laws and statues of the acquiring company prevailing over the acquired company. One of the examples of the cross-border merger is UK's Vodafone AirTouch purchase if Germany's telephone and internet giant Mannesman in 1999.

6. Sixth Wave (2003-2008)

The key features of this wave are globalization, private equity and shareholder activism. Management led to the involvement of the ownership rights of the shareholders in the decisions of the organisations leading to shareholders activism. This does not lead to the direct involvement of the shareholders in the management but now they have a say on how the management or board of directions run it.

This proactive stance taken by shareholders led them to take action in spreading ownership with the management and the investors of the company. This resulted in the influx of private equity. In this wave, globalization played an important role in merger and acquisition even of established and larger companies intending for their expansion in international and global markets.

However, in December 2007, this wave faced the downfall after the subprime mortgage crisis in the US coupled with the recession of the US economy.

7. Seventh Wave (2011- onwards)

The concept of merger and acquisition took a bad shape after the sixth wave after US $\$ 100$ Billion loss suffered by the AOL Time Warner, also known as the 'biggest mistake in corporate merger history'.

Things started to take shape in 2011 when BRICS started taking the forefront of M\&A activity. BRICS stands for Brazil, Russia, India, China and South Africa. The combination was known as the five emerging economies of the world. The five happen to be mostly developing countries and newly industrialized along with the most populous countries. In fact, in 2015, these five countries account for more than $40 \%$ of the world population. This cooperation among the five countries forayed on commercial and corporate activities.

This wave is still practice by incorporating the features of above mentioned six waves like cross-border mergers, hostile takeovers, industrial consolidations and many more. 


\section{Governing Statutes of Merger and Acquisition transactions}

There are many statutes governing the merger and acquisition of the companies as follows:

1. Companies Law, 2013

Merger and Acquisition was governed by Section: 391-394 of the Companies Act, 1956. The new Companies Act, 2013 contains the provisions regarding Compromises, Arrangements and Amalgamations under Chapter XV of the Act containing Sections: 230-240. Under the new Act, an Indian company can merge with any foreign company whether having a place of business in India or not. It is pertinent to note here that earlier under the Companies Act, 1956, there was no such provision regarding the merger of Indian Company with Foreign Company. The Act also contains provisions regarding fast track and simplified procedures for mergers and amalgamations of a certain class of companies such as holding and subsidiary and small companies ${ }^{13}$.

2. Draft Companies (Compromises, Arrangement and Amalgamations) Rules, 2016

The Central Government through the Ministry of Corporate Affairs has also issued draft rules on Compromises, Arrangement and Amalgamations. These rules provide for procedures in Compromises, Arrangement and Amalgamations (Chapter XV) under the Companies Act, 2013.

3. Income Tax Act, 1961

Section: 35(5), 35A (6), 35E (7), 41(4) Explanation 2, 43(1) Explanation 7, 43(6) Explanation 2, 43C, 47 (vi) \&(vii) , 49(1)(iii)(e), 49(2) and 72A of Income Tax Act, 1961 provides tax benefits in case of merger and amalgamation.

According to Section: 2(1B) ${ }^{14}$, amalgamation means the merger of one or more companies with another company or merger of two or more companies to form one company in such a manner that

- All the property of the amalgamating company immediately before the amalgamation becomes the property of the amalgamated company by virtue of amalgamation.

- All the liabilities of the amalgamating company immediately before the amalgamation become the liabilities of the amalgamated company by virtue of amalgamation.

- Shareholders holding not less than $3 / 4$ in the value of shares in the amalgamating company or companies (other than shares already held therein immediately before amalgamation by or by a nominee for, the amalgamated company or its subsidiary) becomes shareholders of the amalgamated company by the virtue of the amalgamation.

4. Accounting Standard-14

The Institute of Chartered Accountant in India has issued Accounting Standard-14 (AS-14) on accounting on Amalgamations. The Standard recognizes two types of amalgamations-

1. Amalgamation in nature of merger; and

2. Amalgamation in nature of the purchase.

5. Foreign Exchange Management Act, 1999

Where the scheme of amalgamation envisages issue of cash/shares option to Non-Resident Indian (NRIs), the amalgamated company is required to obtain the permission of Reserve Bank of India. Regulation 7 of the Foreign Exchange Management (Transfer or Issue of Security by a Person Resident outside India) Regulations, 2000 contains provisions regarding the issue of shares to NRIs under the scheme of amalgamation.

6. Competition Act, 2002

The Competition Act, 2002 replaced the Monopolies and Restrictive Trade Practices Act, 1969. The Act primarily covers three aspects- anti-competitive agreements, abuse of dominance and compromises.

The merger and acquisition are regulated by the Combination Regulations governed by the 'Competition Commission of India (CCI) ${ }^{15}$. The word 'combination, ${ }^{16}$ under the Act means an acquisition of control, shares or voting rights or assets by a person; an acquisition of control of an enterprise where the acquirer already has direct or indirect control of another engaged in similar or identical business; or a merger or amalgamation between or among enterprises, that exceeds the 'financial threshold' prescribed under the Competition Act.

\footnotetext{
${ }^{13}$ Section: 233 of the Companies Act, 2013.

${ }^{14}$ Income Tax Act, 1961.

${ }^{15}$ Chapter III of the Competition Act, 2002.

${ }^{16}$ Section: 5 of the Competition Act, 2002.
} 
7. Indian Stamp Act, 1899

The Act provides for payment of stamp duty. In an amalgamation of companies following kinds of stamp duty is levied:

i. Stamp Duty on the Court Order: The Order of the Court requiring the transfer of the assets and liabilities of the transferor company to the transferee company is a conveyance and hence, chargeable to stamp duty.

ii. Stamp Duty on the other documents: Usually in an amalgamation of companies, several other documents, agreements, indemnity bonds are executed depending upon the facts of each case and requirements of the parties. Stamp duty would also be levied on such documents, agreements, indemnity bonds, as per the nature of the instrument and its contents.

8. Central Value Added Tax (CENVAT) Credit Rules, 2004

Indian Rule 10 of CENVAT Credit Rules, 2004 deals with the transfer of credit. It provides that if a manufacturer of the final product shifts his factory to another side or the factory is transferred on the account of change in ownership or on the account of sale, merger, amalgamation, lease or transfer of the factory to a joint venture with the specific provision for transfer of liabilities of such factory, then the manufacturer shall be allowed to transfer the CENVAT Credit lying unutilized in his accounts to such sold, merged, amalgamated, leased or transferred factory.

Difference between Merger and Acquisition

\begin{tabular}{|c|c|c|}
\hline $\begin{array}{c}\text { BASIS FOR } \\
\text { COMPARISON }\end{array}$ & MERGER & ACQUISITION \\
\hline MEANING & $\begin{array}{l}\text { A merger is a combination of two or more } \\
\text { than two companies coming together } \\
\text { voluntarily to form a new company. }\end{array}$ & $\begin{array}{c}\text { When one entity purchases the business of } \\
\text { another entity, it is known as an } \\
\text { acquisition. }\end{array}$ \\
\hline $\begin{array}{c}\text { FORMATION OF A } \\
\text { NEW COMPANY }\end{array}$ & Yes & No \\
\hline $\begin{array}{c}\text { NATURE OF } \\
\text { DECISION }\end{array}$ & mutual decision & Friendly or hostile decision \\
\hline $\begin{array}{l}\text { MINIMUM NUMBER } \\
\text { OF COMPANIES } \\
\text { INVOLVED }\end{array}$ & 3 & 2 \\
\hline PURPOSE & $\begin{array}{c}\text { To eliminate competition from the market and } \\
\text { synergy of resources, finance and } \\
\text { management. }\end{array}$ & For Instantaneous growth. \\
\hline SIZE OF BUSINESS & More or less the same. & $\begin{array}{l}\text { Acquiring company has more than the } \\
\text { size of the acquired company. }\end{array}$ \\
\hline $\begin{array}{c}\text { LEGAL } \\
\text { FORMALITIES }\end{array}$ & More & Less \\
\hline
\end{tabular}

Main changes involved under the Companies Act, 2013

The field of mergers and acquisitions has undergone tumultuous changes over the past 10 to 15 years. The $1990 \mathrm{~s}$ witnesses the fifth merger wave-a merger wave that was truly international in scope. After a brief recessionary lull, the merger frenzy began once again and global megamergers began to fill the corporate landscape. This was derailed by the subprime crisis and the credit slump that came in its wake. However, the business of M\&A is one which will be ever-present in the corporate world. As the economy expands M\&A go along with it. ${ }^{17}$

The main changes ${ }^{18}$ introduced by The Companies Act, 2013 as regards amalgamation, compromise and reconstruction of companies under the Company Law may be briefly be summarized as follows-

1. The power to sanction compromises and arrangements is exercised by the Tribunal and not the Courts ${ }^{19}$.

\footnotetext{
${ }^{17}$ Patrcik A. Gaughan, Mergers, Acquisitions And Corporate Restructurings, p.no. xv (Wiley, Delhi, fifth edition, 2014).

${ }^{18}$ Dr. N.V. Paranjape, Company Law, p.no. 465 (Central Law Agency, Allahabad, eighth edition, 2017).

${ }^{19}$ Section: 231 of the Companies Act, 2013.
} 
2. Persons holding not less than $10 \%$ of share-holding or having outstanding debt amounting to not less than $5 \%$ of the total debt as per the latest audited financial statement are entitled to object to the scheme of compromise or amalgamation.

3. A compromise or arrangement may include an offer of take-over but shall not include buy-back of securities ${ }^{20}$.

4. If creditors holding at least $90 \%$ value agree to the compromise or arrangement on an affidavit, the Tribunal may dispense with the calling of creditor's meeting.

5. The provision of Section: 66 of the Act, 2013 relating to the reduction of share capital consequent to compromise or arrangement shall not apply where such compromise or arrangement is effected in pursuance of the order of the Tribunal under this Section.

6. Section: 232(2) of The Companies Act, 2013 contains a new provision as to division, i.e. demerger, which did not exist in the earlier Companies Act, 1956.

7. The Companies Act, 2013 permits merger of Indian companies with foreign companies or vice-versa, known as border mergers ${ }^{21}$. This is not provided under the scheme of amalgamation (merger) envisaged under the Companies Act, 2013.

8. An order of dissolution of the company without winding-up shall be made by the Court only after the receipt of the report of the Official Liquidator about the affairs of the company.

These changes are aimed at simplifying and rationalizing the procedures involved in compromises, arrangements and amalgamations and ensuring greater accountability for the companies and majority shareholders and increasing flexibility for corporate entities.

\section{Conclusion:-}

Since 2014, there had been historic changes in the legal and regulatory scenario in India. Movements like "Make in India", "Swachh Bharat", and "Digital India" have revolutionized the economic landscape of India. 2017 witnessed the landscape of lively M\&A space in the country.

Merger and Acquisition plays an important role in corporate restructuring as one size doesn't fit all. Merger and Acquisition are opted by many organizations for expanding their ownership boundaries by the means of a synergy of its resources, management and finance. It changes the scenario within the organizations. Merger and Acquisition comes in all sizes and shapes depending upon the size of the organizations, its assets, shares, stock and even the group of the people involved within. Its impact also depends upon the structure of the deal.

Merger and Acquisition came into a trend in the 1990s after the introduction of LPG policies. But M\&A is not always successful. So it has to be noted here that it is important to assess the cost benefits involved and the optimum strategy required whether $\mathrm{M} \& \mathrm{~A}$ is the nectar of corporate life or poison pill for destruction.

\footnotetext{
${ }^{20}$ Section: 68 of the Companies Act, 2013.
}

${ }^{21}$ Section: 234 of the Companies Act, 2013. 